\title{
Nilai Pendidikan Karakter dan Psikologis Tokoh Utama dalam Novel Sepatu Dahlan Karya Khrisna Pabichara
}

\author{
Ahmad Samsudin ${ }^{1)}$ \\ Universitas Indrprasta PGRI \\ Jalan Nangka No. 58 C/TB. Simatupang, Tanjung Barat, Jakarta Selatan 12530 \\ E. Zaenal Arifin ${ }^{2)}$ \\ Universitas Indrprasta PGRI \\ Jalan Nangka No. 58 C/TB. Simatupang, Tanjung Barat, Jakarta Selatan 12530 \\ Masrin $^{3)}$ \\ Universitas Indrprasta PGRI \\ Jalan Nangka No. 58 C/TB. Simatupang, Tanjung Barat, Jakarta Selatan 12530 \\ shaemzahmad21@gmail.com ${ }^{1)}$, zaenalarifin_48@yahoo.com ${ }^{2)}$

\begin{abstract}
This study aims to determine the values of character education and psychological aspects contained in the novel Shoes Dahlan by Khrisna Pabichara. Character education is an effort designed and carried out systematically to instill students' behavioral values and their implementation in everyday life. The values of character education contained in the novel Shoes Dahlan by Khrisna Pabichara relating to character education consist of: (1) hard work, (2) patience, (3) compassion, (4) sportsmanship, (5) discipline, (6) honest, (7) cooperation, (8) responsibility, (9) curiosity, (10) persistent, and (11) courageous. Based on the discussion of the id, the ego, and the superego of the main character in Khrisna Pabichara's Shoe Shoe Dahlan using Sigmund Freud's psychoanalytic theory; then concluded that the psychological aspect of the main character is a structure consisting of elements of the id, ego, and superego that are interrelated in shaping the various behaviors of the main character.
\end{abstract}

Keywords: Character values, Sigmund Freud's psychoanalysis, and novels

\begin{abstract}
Abstrak
Penelitian ini bertujuan untuk mengetahui nilai-nilai pendidikan karakter dan aspek psikologis yang terdapat dalam novel Sepatu Dahlan karya Khrisna Pabichara. Pendidikan karakter adalah upaya yang dirancang dan dilaksanakan secara sistematis untuk menanamkan nilai-nilai perilaku peserta didik dan implemetasinya dalam kehidupan sehari-hari. Nilai-nilai pendidikan karakter yang terdapat dalam novel Sepatu Dahlan karya Khrisna Pabichara yang berhubungan dengan pendidikan karakter terdiri dari: (1) kerja keras, (2) sabar, (3) kasih sayang, (4) sportif, (5) displin, (6) jujur, (7) kerja sama, (8) tanggung jawab, (9) rasa ingin tahu, (10) gigih, dan (11) berani. Berdasarkan pembahasan id, ego, dan superego tokoh utama dalam Novel Sepatu Dahlan karya Khrisna Pabichara dengan menggunakan teori psikoanalisis Sigmund Freud; maka disimpulkan bahwa aspek psikologis tokoh utama adalah suatu struktur yang terdiri atas unsur id, ego, dan superego yang saling berkaitan dalam membentuk berbagai tingkah laku tokoh utama.
\end{abstract}

Kata kunci : Nilai-nilai karakter, psikoanalisis Sigmund Freud, dan novel.

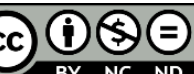

Creative Commons Attribution-NonCommercial-NoDerivatives 4.0 International License 


\section{PENDAHULUAN}

Pendidikan merupakan usaha sadar dan terencana untuk mewujudkan suasana belajar dan proses pembelajaran agar peserta didik secara aktif mengembangkan potensi dirinya untuk memiliki kekuatan spiritual keagamaan, pengendalian diri, kepribadian, kecerdasan, akhlak mulia, serta keterampilan yang diperlukan dirinya dan masyarakat. (Yusti, dkk, 2011: 4). Pendidikan biasanya berawal saat seorang bayi itu dilahirkan dan berlangsung seumur hidup. Pendidikan bisa saja berawal dari sebelum bayi lahir seperti yang dilakukan oleh banyak orang dengan memainkan musik dan membaca kepada bayi dalam kandungan dengan harapan ia bisa mengajar bayi mereka sebelum kelahiran. Oleh sebab itu, penanaman dan penerapan pendidikan karakter dan aspek psikologis dibutuhkan usaha dan upaya lebih kepada setiap anak-anak yang pada essensinya diperlukan pendidikan moral maupun etika dalam berucap maupun bertindak yang dapat dijadikannya sebagai acuan hidup dalam hidup bermasyarakat dan menjadi manusia yang berkarakter baik (person of character), yang berpikiran baik, dan dapat merasakan mana yang baik serta berbuat baik.

Kurangnya pendidikan karakter yang ditanamkan oleh kalangan masyarakat baik itu orang tua, guru, lingkungan keluarga dan masyarakat sekitar kepada anakanak sejak dini. Hingga hal itu menyebabkan terjadinya krisis multi dimensi dan keterpurukan dipelbagai dimensi pribadi anak-anak yang nantinya dipersiapkan sebagai generasi penerus bangsa dan nilai-nilai pendidikan yang telah tertanam pada pribadi anak-anak Indonesia dapat diimplementasikan dengan baik, bukan tidak mungkin Indonesia dapat mengembalikan martabat dan harkatnya di mata dunia. Pendidikan karakter harus kita tanamkan secara konsisten kepada anak-anak penerus bangsa ini, guna melahirkan generasi yang dapat menghindarkannya dari karakter-karakter buruk yang dapat menjatuhkan sendi-sendi kehidupan dalam masyarakat Indonesia yang berbudaya dan berkarakter.

Karya sastra (fiksi) merupakan kehidupan buatan atau rekaan sastrawan. Sesuatu yang disampaikan oleh sastrawan dalam karyanya adalah tentang manusia dan segala macam prilakunya. "Sebagai dunia dalam kata, karya sastra memasukan berbagai aspek kehidupan di dalamnya, khususnya manusia" (Ratna, 2015: 343). Kehidupan manusia itu diungkapkan lengkap dengan nilai-nilai yang terkandung di dalamnya. Oleh karena itu, setiap kejadian yang terjadi dalam kehidupan ini terkandung nilai-nilai atau hikmah yang dapat dipetik manfaatnya."Fiksi menawarkan "model-model" kehidupan sebagaimana diidealkan oleh pengarang sekaligus menunjukan sosoknya sebagai karya seni yang berunsur estetik dominan" (Nurgiyantoro, 2005: 3). Di sini sastra tidak banyak berhubungan dengan tulisan, tetapi dengan bahasa yang dijadikan wahana untuk mengekspresikan pengalaman atau pemikiran tertentu.

Selanjutnya, novel merupakan karya sastra yang mengungkapkan berbagai aspek di dalam masyarakat, yang dibangun melalui unsur intrinsik dan ekstrinsik serta nilai-nilai yang terkandung di dalamnya. Begitu pula yang terjadi dalam novel Sepatu Dahlan karya Khrisna Pabichara yang merupakan sebuah totalitas yang terbangun oleh berbagai unsur intrinsiknya yang koherensi dan padu. Novel yang terinspirasi dari sosok nyata kehidupan anak laki-laki yang bernama Dahlan Iskan 
yang dulunya menjadi menteri BUMN pada masa kepemimpinan presiden SBY. Dengan mempelajari unsur intrinsik novel Sepatu Dahlan yang meliputi tema, alur (plot), tokoh dan penokohan, gaya bahasa, latar (setting), sudut pandang (point of view), dan amanat pada novel ini akan didapatkan nilai-nilai pendidikan yang terkandung di dalamnya sehingga mampu mempengaruhi perkembangan peserta didik menjadi masyarakat yang berkarakter dan bermoral. Nilai-nilai Pendidikan dan aspek psikologis tokoh utama itu jika digali dan diajarkan dapat membentuk karakter siswa yang berbudi luhur dan dapat menempa jiwa mereka menjadi pribadi-pribadi yang tangguh dan mampu mengimplementasikan karakter dan moral tersebut dalam kehidupannya sehari-hari.

Novel ini mengisahkan tentang perjuangan hidup yang patut dipelajari dan diteladani bagi siapapun yang di dalam dirinya terkobar api optimisme dan pantang menyerah akan cobaan dan kesulitan hidup yang menerpanya. Banyak nilai-nilai karakter yang dapat kita petik dan jadikan contoh dalam kehidupan kita sehari-hari. Disadari atau tidak bahwasanya pendidikan karakter itu memiliki peranan yang amat penting dalam sendi-sendi kehidupan ini. Khususnya di Negara Kesatuan Republik Indonesia ini, bangsa yang terkenal dengan etika dan sopan-santunya, sebagai negara yang mayoritas memeluk agama Islam terbanyak di dunia. Hal inilah yang menjadi keinginan penulis untuk merefleksikan kembali tentang penting pendidikan karakter atau moral bagi anak-anak penerus bangsa.

Novel Trilogi karya Khrisna Pabichara ini memberikan pandangan hidup untuk kita semua bahwa kita harus jujur, sabar dan tabah dalam menghadapi persoalan hidup. Harus kuat dan sabar serta tidak putus asa karena kemiskinan tidak meski diratapi namun harus dijalani sebagaimana mestinya. Nilai-nilai yang terkandung dalam novel ini mengajarkan kita bahwa hidup itu harus diperjuangkan dan dilalui sesulit apapun kehidupan yang kita alami.

Berdasarkan hal tersebut penulis berkeinginan untuk menelaah atau meneliti novel Sepatu Dahlan secara langsung. Karya sastra yang dibuat oleh Khrisna Pabichara tersebut sangat menyentuh, membangun karakter siswa, penuh dengan filosofis kehidupan yang harus dijalani, menarik dan memiliki unsur pembentukan karakter yang tinggi dalam kepribadian siswa. Novel ini berangkat dari kisah nyata dan sosok Dahlan masa kecil yang menjadi inspirasi bagi setiap pribadi siswa yang harus berjuang dan bersungguh-sungguh untuk dapat mengejar cita-citanya. Siapapun berhak mereguk ilmu sebanyak-banyaknya meski memiliki kekurangan dari segi ekonomi.

\section{METODE}

Metode penelitian atau research method diutarakan oleh Ali (2011: 168) merupakan aspek aksiologi dari suatu paradigma, yang merupakan aspek nyata cara melaksanakan penelitian. Di dalamnya terdapat jenis penelitian, data, sumber data, dan metode penelitian yang meliputi pengadaan, analisis, dan penyajian data.

Penelitian ini merupakan jenis penelitian kualitatif deskriptif. Penelitian kualitatif menurut Moleong (2017: 6) adalah penelitian untuk memahami fenomena tentang apa yang dialami oleh subjek penelitian misalnya perilaku, persepsi, motivasi, tindakan dan lain-lain, secara holistik dan cara deskripsi dalam bentuk kata-kata 
dan bahasa. Penelitian ini menganalisis nilai-nilai pendidikan karakter dan aspek psikologi tokoh utama dalam novel Sepatu Dahlan karya Khrisna Pabichara dengan melihat bagian cerita disetiap bab yang ada di dalamnya. Adapun pendekatan yang dilakukan oleh peneliti adalah pendekatan psikologis. "Pendekatan psikologis adalah pendekatan yang bertolak dari asumsi bahwa karya sastra selalu saja membahas tentang peristiswa kehidupan manusia" (Semi, 2012: 76). Manusia senantiasa memperlihatkan prilaku yang beragam, bila ingin melihat dan mengenal manusia lebih jauh diperlukan psikologi. Menurut Endaswara (2008: 96) Asumsi dasar penelitian psikologi sastra anatar lain dipengaruhi oleh beberapa hal. Pertama, adanya anggapan bahwa karya sastra merupakan produk dari suatu kejiwaan dan pemikiran perngarang yang berada pada situasi setengah sadar atau subconcius setelah jelas baru dituangkan ke dalam bentuk secara sadar. Antara sadar dan tak sadar selalu mewarnai dalam proses imajinasi pengarang.

Kekuatan karya sastra dapat dilihat dari seberapa jauh pengarang mampu mengungkapkan ekspresi kejiwaan yang tak sadar itu kedalam cipta sastra. Kedua, kajian psikologi sastra disamping meneliti perwatakan tokoh secara psikolgis juga aspek-aspek pemikiran dan perasaan pengarang ketikn menciptakan karya tersebut. Seberapa jauh pengarang mampu menggambarkan perwatakan atau karakter tokoh sehingga karya semakin hidup. Sentuhan-sentuhan emosi melalui dialog ataupun pemilihan kata, sebenarnya merpakan gambaran kekuatan dan kejernihan batin pencipta. Selanjutnya untuk pendekatan psikologi sastra yang peneliti gunakan dalam melakukan kajian yakni dengan metode analisis psikoanalisis Sigmund Freud yang di dalamnya mengupas habis tentang struktur kepribadian terdiri dari tiga sistem yaitu id, (das es), ego (das ich), dan super ego (das ueber ich). Menurut Ratna, (2015: 62) Karya sastra dianggap sebagai hasil aktivitas penulis, yang sering dikaitkan dengan gelaja-gejala kejiwaan. Perilaku manusia pada hakikatnya merupakan hasil interaksi substansi dalam kepribadian manusia id, ego, dan super ego yang ketiganya selalu bekerja, jarang salah satu di antaranya terlepas atau bekerja sendiri. (Bartens, 2016: 14)

\section{HASIL DAN PEMBAHASAN}

\section{Hasil}

Alur yang terdapat dalam novel Sepatu Dahlan karya Khrisna Pabichara terdiri atas: (1) Prolog dari halaman satu sampai halaman Sembilan, (2) 32 episode dari halaman tiga belas sampai halaman tiga ratus lima puluh sembilan dan (3) epilog dari halaman tiga ratus enam puluh empat sampai halaman tiga ratus lima puluh Sembilan. Secara kuantitas dapat digolongkan dalam alur campuran. Kronologis cerita novel keseluruhan diceritakan secara acak.

Tema yang terdapat dalam novel Sepatu Dahlan karya Khrisna Pabichara adalah tentang perjuangan hidup. Novel Sepatu Dahlan mengamanatkan kepada pembaca, antara lain: (1) kemiskinan bukanlah halangan untuk meraih cita-cita, kemauan yang keras untuk meraih cita-cita, bekerja keras dng segenap kemampuan dan keterbatasan hidup, dan menjadi anak yang tangguh adalah kunci untuk mencapai cita-cita, (2) jangan pernah menyerah oleh keadaan, (3) hidup dalam belenggu kemiskinan harus dijalani apa adanya dan tidak mengenal kata putus asa, 
karena seberat apapun kehidupan yang kita alami harus dijalani dng penuh rasa syukur dan apa adanya.

Dalam nilai-nilai pendidikan karakter dalam novel Sepatu Dahlan karya Khrisna Pabichara yang berhubungan dengan nilai-nilai pendidikan karakter terdiri dari: (1) kerja keras, (2) sabar, (3) kasih sayang, (4) sportif, (5) disiplin, (6) jujur, (7) kerja sama, (8) tanggung jawab, (9) rasa ingin tahu, (10) gigih, dan (11) berani. Berikut deskripsi data tentang nilai-nilai pendidikan karakter yang terdapat dalam novel Sepatu Dahlan karya Khrisna Pabichara. Sosok Dahlan yang menjadi tokoh utama dalam novel Sepatu Dahlan dilihat dari aspek psikologis dapat dipahami melalui : id, ego, dan superego dengan menggunakan teori psikoanalisis Sigmund Freud.

\section{Pembahasan}

Unsur-unsur intrinsik merupakan unsur-unsur pembangun karya sastra yang dapat ditemukan di dalam teks karya sastra itu sendiri. Analisis intrinsik adalah mencoba memahami suatu karya sastra berdasarkan informasi-informasi yang dapat ditemukan di dalam karya sastra itu atau secara eksplisit terdapat dalam karya sastra. Hal ini didasarkan pada pandangan bahwa suatu karya sastra menciptakan dunianya sendiri yang berbeda dari dunia nyata. Segala sesuatu yang terdapat dalam dunia karya sastra merupakan fiksi yang dapat berhubungan dengan dunia nyata. Unsur intrinsik sebuah novel mencakup tema, latar/setting, alur/plot, penokohan/perwatakan, sudut pandang, amanat, konflik dan gaya bahasa.

Deskripsi nilai-nilai pendidikan karakter dan aspek psikologis tokoh utama dalam novel Sepatu Dahlan karya Khrisna Pabichara. Data hasil penelitian yang telah dilakukan oleh penulis ditemukan adanya nilai-nilai pendidikan karakter sebanyak 11 butir dan aspek psikologis id, ego, dan superego. Adapun nilai-nilai pendidikan karakter yang ditemukan dalam novel tersebut adalah sebagai berikut: Nilai-nilai pendidikan karakter yang terdapat dalam novel Sepatu Dahlan karya Khrisna Pabichara yang berhubungan dengan pendidikan karakter terdiri dari: (1) kerja keras, (2) sabar, (3) kasih sayang, (4) sportif, (5) displin, (6) jujur, (7) kerja sama, (8) tanggung jawab, (9) rasa ingin tahu, (10) gigih, dan (11) berani. Berdasarkan pembahasan id, ego, dan superego tokoh utama dalam Novel Sepatu Dahlan karya Khrisna Pabichara dengan menggunakan teori psikoanalisis Sigmund Freud; maka disimpulkan bahwa aspek psikologis tokoh utama adalah suatu struktur yang terdiri atas unsur id, ego, dan superego yang saling berkaitan dalam membentuk berbagai tingkah laku tokoh utama. Id tokoh utama adalah unsur kepribadian tokoh utama yang terdiri atas dorongan-dorongan naluri dalam bentuk keinginan memenuhi kebutuhan kasih sayang, harga diri, bersepatu, bersepeda, menghilangkan rasa lapar atau mendapatkan makanan, dan bermain voli.

Ego tokoh utama adalah unsur kepribadian tokoh utama yang berfungsi mengarahkan tokoh utama pada rencana pemenuhan kebutuhan-kebutuhan id secara nyata serta berdasarkan aturan dan nilai Islam yang berlaku dalam lingkungan keluarganya maupun masyarakat Magetan (superego), menyeimbangkan antara dorongan id dengan superego, serta mereduksikan teganga atau kecemasan dengan mekanisme-mekanisme pertahanan. 
Superego tokoh utama adalah unsur kepribadian tokoh utama yang terbentuk berdasarkan penerapan aturan dan nilai Islam dalam keluarganya dan masyarakat desa Kebon Dalem, yang berfungsi sebagai pengendali dorongan id dan ego. Superego itu sendiri juga muncul dalam bentuk rasa bersalah dan menyesal karena telah melakukan kesalahan, serta rasa senang atau riang setelah melakukan perbuatan terpuji.

\section{SIMPULAN}

Berdasarkan hasil penelitian yang telah dilakukan dalam novel Sepatu Dahlan karya Khrisna Pabichara, dapat diambil beberapa simpulan, yaitu nilai-nilai pendidikan karakter yang terdapat dalam novel Sepatu Dahlan karya Khrisna Pabichara yang berhubungan dengan pendidikan karakter terdiri dari: (1) kerja keras, (2) sabar, (3) kasih sayang, (4) sportif, (5) displin, (6) jujur, (7) kerja sama, (8) tanggung jawab, (9) rasa ingin tahu, (10) gigih, dan (11) berani dan berdasarkan pembahasan id, ego, dan superego tokoh utama dalam Novel Sepatu Dahlan karya Khrisna Pabichara dengan menggunakan teori psikoanalisis Sigmund Freud; maka disimpulkan bahwa aspek psikologis tokoh utama adalah suatu struktur yang terdiri atas unsur id, ego, dan superego yang saling berkaitan dalam membentuk berbagai tingkah laku tokoh utama.

\section{DAFTAR PUSTAKA}

Ali, M. (2011). Memahami riset perilaku dan sosial. Bandung: Pustaka Cendikia Utama

Bartens, K. (2016). Psikoanalisis sigmun freud. Jakarta: Gramedia Pustaka Utama.

Endraswara, S. (2008). Metodologi penelitian sastra. Yogyakarta: Media Pressindo.

Moleong, L. J. (2017). Metodologi penelitian kualitatif. Bandung: Remaja Rosdakarya.

Nurgiyantoro, B. (2005). Teori pengkajian fiksi. Yogyakarta: Gajah Mada University Press.

Pabichara, K. (2012). Sepatu Dahlan. Jakarta: Mizan Publika.

Ratna, N. K. (2015). Teori, metode, dan teknik penelitian sastra. Yogyakarta: Pustaka Pelajar.

Semi, M. A. (2012). Metode penelitian sastra. Bandung: Angkasa.

Yusti, P., Handoyo, S., \& Matulessy, A. (2011). Pendidikan karakter perspektif guru dan psikolog. Malang: Selaras. 